\title{
Evaluation of Added Sugar and Sugar-Sweetened Beverage Consumption by University Students
}

\author{
Çağdaş Salih Meric1" ${ }^{*}$ Nurcan Yabanci Ayhan'1, Hacı Ömer Yilmaz²
}

${ }^{1}$ Department of Nutrition and Dietetics, Faculty of Health Sciences, Ankara University, Ankara, Turkey

2Department of Nutrition and Dietetics, Faculty of Health Sciences, Gümüşhane University, Gümüşhane, Turkey

\begin{abstract}
Today, increased intake of sugar and sugar-sweetened beverages is seen as an important factor in the growing prevalence of chronic diseases, such as obesity, obesity-related diabetes, and coronary heart diseases. This study involved 214 Ankara University students from the Department of Nutrition and Dietetics, which was intended to evaluate the consumption of sugar and sugar-sweetened beverages. The frequency of student consumption of beverages and the quantities and amounts of sugar taken with beverages were questioned. The average total amount of sugar added to drinks by the students was 4.69 \pm 6.35 gram, while the average total amount of sugar taken with sugar-sweetened beverages was $11.34 \pm 15.32$ gram. Female students relative to male students, students in grade 4 compared to grades 2 and 3 , and students who had daily breakfast compared to those who did not had lower average sugar consumption ( $p$-value $<0.05$ ). As class grades increase, the amount of sugar added to beverages and fruit juice and sweetened soft drinks and carbonated beverages decreased $(p$-value $<0.05)$. The consumption of herbal teas and dietary beverages increased and the eating habits of students generally changed positively ( $p$-value $>0.05$ ). It is important to educate university students about the reduction in sugar intake and sugar-containing food in order to avoid many chronic diseases that may be seen in older ages.
\end{abstract}

Keywords: sugar, sugar-sweetened beverages, university students

\section{Introduction}

Obesity is a significant health concern in both developed and developing countries today. There have been several factors in the etiology of obesity, but the association between increased obesity prevalence and high sugar consumption has gained attention recently. ${ }^{1}$ Moreover, the relationship between high sugar consumption and health problems such as obesity, diabetes, cardiovascular diseases, dental caries, and hyperactivity is discussed. ${ }^{2-5}$

Experimental and observational studies have shown that the amount of sugar added to beverages or taken by sweetened beverages induces weight gain in children and adults. It is also strongly emphasized that this situation is closely linked to diseases such as oral and dental health, cardiovascular diseases, diabetes, and metabolic syndrome. ${ }^{6-9}$ Studies in Turkey indicate that $68.8 \%$ of young people consumed sugar added tea and coffee, $33.2 \%$ consumed cola drinks, $46.4 \%$ consumed fruit juice, and $49.2 \%$ consumed foods such as sugar and chocolate; 10 30\% preferred milk and fruit juice as a drink

Correspondence* : Cağdaș Salih Meric, Department of Nutrition and Dietetics, Faculty of Health Sciences, Ankara University, Ankara, Turkey, Email: csmeric@ankara.edu.tr,Phone: (0312) 3812350 at breakfast; ${ }^{11} 10.6 \%$ of students consumed cola, and $19.9 \%$ consumed fruit juice. ${ }^{12}$ Other studies stated that most young people prefer cola drinks between meals. ${ }^{11,13}$ Another study conducted in Turkey found that $11.5 \%$ of young people consumed sweetened carbonated beverages or cola drinks every day. ${ }^{14}$

Nowadays, sugar added or sugar-sweetened fruit juices, soft drinks, and carbonated beverages take place in nutritious drinks such as milk and ayran. ${ }^{15}$ Little is known about factors that determine the preferences of beverages as well as the influence of university students on the consumption of sweetened beverages by many factors. In order to better understand these factors, there is a need for the planning and implementation of dietary habits, particularly for the consumption of sweetened beverages by young people. It is considered that this aspect should be taken into account when evaluating the risk of chronic diseases associated with nutrition and health-promoting and protective practices.

For that reason, this study was organized and conducted to determine the amount of sugar added to bever- 
ages or taken by sweetened beverages and the number of beverages consumed by $2^{\text {nd }}$, $3^{\text {rd }}$, and $4^{\text {th }}$-year students studying at the Faculty of Health Sciences, Department of Nutrition and Dietetics of Ankara University, Turkey.

\section{Method}

This study was conducted between November and December 2016 in a total of 214 students in the $2^{\text {nd }}$, $3^{\text {rd, }}$ and $4^{\text {th }}$ years of the Faculty of Health Sciences, Department of Nutrition and Dietetics of Ankara University, Turkey. This study involved all students (214 students) studying at the Department of Nutrition and Dietetics (the second, third, and fourth years).

Data from the survey were obtained by applying a face-to-face questionnaire, which consists of two parts. The first part contains some demographic information on students and some nutritional habits, such as having breakfast daily and eating outside the house. The second part includes information on students' beverage consumption (daily water consumption; frequency of tea, herbal teas, Nescafe, milk, etc.; addition of sugar to some beverages; preference of sweetened beverages; etc.).

Beverage consumption by university students was determined by frequency and quantity. Moreover, it was questioned how much and how often students consumed drinks such as milk, ayran, fruit juice, cola or diet drinks, Nescafe, Turkish coffee, energy drinks, and alcohol (e.g., one cup a day, one cup of water at a time). University students were asked to complete the surveys, taking into account the frequency of beverage consumption in the last three months. Beverage frequency consumption of each item was evaluated using seven categories: never, once a week, two to three times per week, four to six times per week, once a day, two to three times per day, and four to eight times per day. Later, beverage consumption coefficients were multiplied by the number of drinks consumed at one time. The amount of beverage consumed by university students per day was calculated in $\mathrm{mL}$.

Daily beverage intake was determined using the following formula: frequency of intake (the conversion factor) $\times$ serving size $\times$ total number of servings $\times \mathrm{mL}$ of beverage in one serving. ${ }^{16}$ Water consumption of university students questioned in the form of water glass. Students who added sugar to beverages were asked to write down the amount of sugar they added as a teaspoon, depending on the amount they consumed (one teaspoon, one cup, etc.), and the amount of sugar added to beverages is calculated in grams, taking into account the amount of beverage consumed. In this study, one teaspoon of sugar was accepted as 5 grams. ${ }^{17}$ In addition, sugar fractions used in sweetened beverages are taken from the official websites of the related beverage companies and the amount of sugar taken from sweetened bev- erages, and finally, the total amount of sugar is calculated. ${ }^{18-21}$

Statistical evaluation was assessed using the Statistical Package for the Social Sciences (SPSS) version 24 (IBM SPSS Advanced Statistics 24.0, Program Number: 5725-A54). Charts showing mean and percent values were prepared when the frequency of beverages was evaluated. One-way ANOVA was used to assess sugar consumed in sweetened beverages and the amount of daily consumption of some beverages and drinks. Further, independent samples of $t$-tests were used to assess sugar consumption among groups where demographic information and nutrition habits are considered. Additionally, the significance level was accepted as p-value $<0.05$ in all statistical analyses. The study was approved by the Ethics Committee of Ankara University (Approval ID: 06-258-16).

\section{Results}

A total of 214 university students (21 males, $193 \mathrm{fe}$ males) participated in the study, with a mean age of $20.57 \pm 1.10$ years and a mean number of siblings of $3.04 \pm 1.52$. According to Table $1,18.7 \%$ of university students say they drink milk once a day, $39.3 \%$ drink ayran two to three times a week, $38.9 \%$ drink tea two to three times a day, and $35.0 \%$ drink Turkish coffee once a week. In addition, $98.6 \%$ of students did not consume energy drinks, 93.9\% turnip, 89.7\% alcoholic beverages, $82.7 \%$ diet drinks, $65.4 \%$ mineral water, $64.5 \%$ of pure fruit juices, and $56.5 \%$ carbonated drinks.

University students' consumption of carbonated beverages, fruit juice, sweetened tea, and sweetened soft drinks ( $\mathrm{mL} /$ day) were lower as the class level increased, whereas consumption of herbal tea and diet beverages increased (Table 2). The average daily water consumption of university students was $1228.04 \pm 533.5 \mathrm{~mL} /$ day.

Table 3 indicates the amount of sugar (gram) added to beverages by university students and the amount of sugar taken with sweetened beverages by grade level ( 2 , $3,4)$. Accordingly, as the grade level increases, the amount of sugar added to beverages and the amount of sugar taken with sweetened beverages are reduced. The average amounts of sugar added to all beverages are 7.21 $\pm 7.43 \mathrm{~g}, 3.64 \pm 5.39 \mathrm{~g}$, and $2.15 \pm 3.95 \mathrm{~g}$ in grades 2,3 , and 4 , respectively. The total amounts of sugar taken with sweetened beverages for $2^{\text {nd }}, 3^{\text {rd }}$, and $4^{\text {th }}$ grades, respectively, are $17.09 \pm 21.62 \mathrm{~g}, 8.56 \pm 14.53 \mathrm{~g}$, and $7.08 \pm 8.57 \mathrm{~g}$.

When the amount of sugar consumed by students is considered in line with some nutritional habits; students who have obese individuals in their families, who have daily breakfast regularly, and who have not consumed anything before sleeping had significantly lower sugar consumption. However, students who added salt without 
Table 1. Frequency of Some Beverages Consumption by University Students in Ankara City, Turkey $(\mathrm{N}=214)$

\begin{tabular}{|c|c|c|c|c|c|c|c|c|c|c|c|c|c|c|}
\hline \multirow{3}{*}{ Beverage } & \multicolumn{6}{|c|}{ Per Day } & \multicolumn{6}{|c|}{ Per Week } & \multirow{2}{*}{\multicolumn{2}{|c|}{ Never }} \\
\hline & \multicolumn{2}{|c|}{ Four to Eight Times } & \multicolumn{2}{|c|}{ Two to Three Times } & \multicolumn{2}{|c|}{ One Time } & \multicolumn{2}{|c|}{ Four to Six Times } & \multicolumn{2}{|c|}{ Two to Three Times } & \multicolumn{2}{|c|}{ One Time } & & \\
\hline & $\mathbf{n}$ & $\%$ & $\mathbf{n}$ & $\%$ & $\mathbf{n}$ & $\%$ & $\mathbf{n}$ & $\%$ & $\mathbf{n}$ & $\%$ & $\mathbf{n}$ & $\%$ & $\mathbf{n}$ & $\%$ \\
\hline Milk & - & - & 11 & 5.1 & 40 & 18.7 & 33 & 15.4 & 67 & 31.3 & 49 & 22.9 & 14 & 6.5 \\
\hline Ayran & - & - & 2 & 0.9 & 9 & 4.2 & 26 & 12.1 & 84 & 39.3 & 77 & 36.0 & 16 & 7.5 \\
\hline Pure fruit juice & - & - & - & - & - & - & 2 & 0.9 & 16 & 7.5 & 58 & 27.1 & 138 & 64.5 \\
\hline Fruit juice & - & - & - & - & 3 & 1.4 & 9 & 4.2 & 35 & 16.4 & 57 & 26.6 & 110 & 51.4 \\
\hline Carbonated drinks & - & - & - & - & - & - & 5 & 2.3 & 24 & 11.2 & 64 & 29.9 & 121 & 56.5 \\
\hline Diet drinks (zero, light, etc.) & - & - & - & - & - & - & 1 & 0.5 & 10 & 4.7 & 26 & 12.1 & 177 & 82.7 \\
\hline Black tea & 20 & 9.3 & 83 & 38.9 & 55 & 25.7 & 17 & 7.9 & 22 & 10.3 & 9 & 4.2 & 8 & 3.7 \\
\hline Sweetened tea (ice tea, etc.) & - & - & 1 & 0.5 & 3 & 1.4 & 8 & 3.7 & 13 & 6.1 & 52 & 24.3 & 137 & 64.0 \\
\hline Herbal teas & 1 & 0.5 & 5 & 2.3 & 12 & 5.6 & 15 & 7.0 & 46 & 21.5 & 59 & 27.6 & 76 & 35.5 \\
\hline Nescafe & 3 & 1.4 & 16 & 7.5 & 25 & 11.7 & 24 & 11.2 & 54 & 25.2 & 51 & 23.8 & 41 & 19.2 \\
\hline Turkish coffee & - & - & 3 & 1.4 & 11 & 5.1 & 13 & 6.1 & 33 & 15.4 & 75 & 35.0 & 79 & 36.9 \\
\hline Mineral water & - & - & - & - & 3 & 1.4 & 7 & 3.3 & 15 & 7.0 & 49 & 22.9 & 140 & 65.4 \\
\hline Sweetened soft drinks & - & - & - & - & - & - & 2 & 0.9 & 12 & 5.6 & 63 & 29.4 & 137 & 64.0 \\
\hline Oralet & - & - & - & - & - & - & 1 & 0.5 & 2 & 0.9 & 10 & 4.7 & 201 & 93.9 \\
\hline Turnip & - & - & - & - & - & - & 1 & 0.5 & 2 & 0.9 & 10 & 4.7 & 201 & 93.9 \\
\hline Energy drinks & - & - & - & - & - & - & - & - & - & - & 3 & 1.4 & 211 & 98.6 \\
\hline Alcoholic beverages & - & - & - & - & - & - & - & - & 5 & 2.3 & 17 & 7.9 & 192 & 89.7 \\
\hline
\end{tabular}

Table 2. Consumption Amounts of Some Beverages Consumed by University Students $(\mathrm{N}=214)(\mathrm{mL} / \mathrm{day})$

\begin{tabular}{|c|c|c|c|c|c|c|}
\hline \multirow{3}{*}{ Beverage } & \multicolumn{4}{|c|}{ Amount of Consumed Beverage (mL/day) } & \multirow[b]{3}{*}{$\mathbf{F}$} & \multirow[b]{3}{*}{ p-value } \\
\hline & $2^{\text {nd }}$ Grade $(N=84)$ & $3^{\text {rd }}$ Grade $(N=79)$ & $4^{\text {th }}$ Grade $(N=51)$ & Total $(\mathrm{N}=214)$ & & \\
\hline & $\bar{x} \pm$ SD & $\bar{x} \pm$ SD & $\bar{x} \pm$ SD & $\bar{x} \pm$ SD & & \\
\hline Milk & $195.23 \pm 77.46$ & $193.03 \pm 55.31$ & $184.31 \pm 67.44$ & $191.82 \pm 67.42$ & 0.435 & 0.64 \\
\hline Ayran & $210.71 \pm 83.61$ & $205.82 \pm 73.91$ & $186.27 \pm 80.04$ & $203.08 \pm 79.51$ & 1.582 & 0.20 \\
\hline Pure fruit juice & $106.07 \pm 106.14$ & $62.40 \pm 96.15$ & $35.29 \pm 77.00$ & $73.08 \pm 99.90$ & 9.359 & $\begin{array}{l}0.00^{\mathrm{a}} \\
0.01^{\mathrm{b}}\end{array}$ \\
\hline Fruit juice & $175.00 \pm 176.59$ & $110.12 \pm 145.48$ & $69.21 \pm 108.12$ & $125.84 \pm 156.39$ & 8.442 & $\begin{array}{l}0.00^{\mathrm{a}} \\
0.01^{\mathrm{b}}\end{array}$ \\
\hline Carbonated drinks & $136.30 \pm 140.68$ & $98.35 \pm 143.93$ & $90.98 \pm 121.41$ & $111.49 \pm 138.44$ & 2.293 & 0.10 \\
\hline Diet drinks & $25.35 \pm 70.70$ & $43.67 \pm 98.30$ & $59.21 \pm 108.32$ & $40.18 \pm 91.75$ & 2.278 & 0.10 \\
\hline Black tea & $192.85 \pm 131.52$ & $185.44 \pm 159.35$ & $205.00 \pm 151.27$ & $193.01 \pm 146.51$ & 0.274 & 0.76 \\
\hline Sweetened tea & $102.26 \pm 132.04$ & $97.97 \pm 151.81$ & $90.98 \pm 159.81$ & $97.99 \pm 145.77$ & 0.094 & 0.91 \\
\hline Herbal teas & $98.80 \pm 91.16$ & $115.08 \pm 92.64$ & $117.68 \pm 96.17$ & $109.57 \pm 92.88$ & 0.932 & 0.39 \\
\hline Nescafe & $144.04 \pm 79.68$ & $134.17 \pm 90.42$ & $174.50 \pm 121.80$ & $147.66 \pm 95.89$ & 2.890 & 0.58 \\
\hline Turkish coffee & $76.19 \pm 63.28$ & $70.88 \pm 55.81$ & $67.64 \pm 70.58$ & $72.19 \pm 62.31$ & 0.324 & 0.72 \\
\hline Mineral water & $91.66 \pm 124.38$ & $52.27 \pm 91.49$ & $63.72 \pm 92.23$ & $70.46 \pm 106.78$ & 2.956 & 0.054 \\
\hline Sweetened soft drinks & $102.73 \pm 102.51$ & $56.32 \pm 91.41$ & $46.07 \pm 84.16$ & $72.10 \pm 97.17$ & 7.472 & $\begin{array}{l}0.02^{\mathrm{a}} \\
0.00^{\mathrm{b}}\end{array}$ \\
\hline
\end{tabular}

Notes: $\mathrm{p}$-value $<0.05^{\mathrm{a}}=$ the level of significance between the $2^{\text {nd }}$ and $4^{\text {th }}$ grades; $\mathrm{p}$-value $<0.05^{\mathrm{b}}=$ the level of significance between the $2^{\text {nd }}$ and $3^{\text {rd }}$ grades; SD $=$ Standar Deviation

tasting their meals were found to have significantly higher average sugar consumption than those who did not ( $\mathrm{p}$ value $<0.05)$ (Table 4).

\section{Discussion}

The mean age of 214 university students involved in the study was $20.57 \pm 1.10$ years. Furthermore, $38.9 \%$ of university students consumed tea two to three times a day, and $35.0 \%$ consumed Turkish coffee once a week. In addition, $51.4 \%$ of students did not consume fruit juice, $56.5 \%$ carbonated drinks, $35.5 \%$ herbal tea,
$65.4 \%$ mineral water, and $89.7 \%$ alcoholic beverages.

The mean age of 214 university students involved inthe study was $20.57 \pm 1.10$ years. Furthermore, $38.9 \%$ of university students consumed tea two to three times aday, and $35.0 \%$ consumed Turkish coffee once a week.In addition, $51.4 \%$ of students did not consume fruitjuice, $56.5 \%$ carbonated drinks, $35.5 \%$ herbal tea, $65.4 \%$ mineral water, and $89.7 \%$ alcoholic beverages. According to Türkiye Beslenme ve Sağlık Araştırması (TBSA)/Turkey Nutrition and Health Research data, ${ }^{22}$ when the frequency of consumption of 
Table 3. Evaluation of the Amount of Sugar Added to $100 \mathrm{~mL}$ of Some Beverages According to Grades of University Students (g)

\begin{tabular}{|c|c|c|c|c|c|c|}
\hline & \multicolumn{4}{|c|}{ Amount of Sugar Added (g) } & \multirow[b]{3}{*}{$\mathbf{F}$} & \multirow[b]{3}{*}{ p-value } \\
\hline & $2^{\text {nd }}$ Grade $(N=84)$ & $3^{\text {rd }}$ Grade $(N=79)$ & $4^{\text {th }}$ Grade $(\mathrm{N}=51)$ & Total $(\mathrm{N}=214)$ & & \\
\hline & $\bar{x} \pm$ SD & $\bar{x} \pm$ SD & $\bar{x} \pm$ SD & $\bar{x} \pm$ SD & & \\
\hline Sugar added to tea & $2.26 \pm 2.33$ & $1.11 \pm 1.65$ & $0.82 \pm 1.60$ & $1.49 \pm 2.03$ & 11.09 & $\begin{array}{l}0.001^{\mathrm{a}} \\
0.000^{\mathrm{b}}\end{array}$ \\
\hline Sugar added to herbal tea & $1.85 \pm 2.33$ & $0.86 \pm 1.93$ & $0.35 \pm 0.95$ & $1.13 \pm 2.02$ & 10.76 & $\begin{array}{l}0.003^{\mathrm{a}} \\
0.000^{\mathrm{b}}\end{array}$ \\
\hline Sugar added to Nescafe & $2.00 \pm 2.59$ & $1.24 \pm 1.90$ & $0.82 \pm 1.55$ & $1.43 \pm 2.18$ & 5.34 & $0.006^{\mathrm{b}}$ \\
\hline Sugar added to milk & $1.09 \pm 2.11$ & $0.43 \pm 1.34$ & $0.15 \pm 0.67$ & $0.62 \pm 1.63$ & 6.45 & $\begin{array}{l}0.023^{\mathrm{a}} \\
0.003^{\mathrm{b}}\end{array}$ \\
\hline Total sugar added to beverages & $7.21 \pm 7.43$ & $3.64 \pm 5.39$ & $2.15 \pm 3.95$ & $4.69 \pm 6.35$ & 13.09 & $\begin{array}{l}0.001^{\mathrm{a}} \\
0.000^{\mathrm{b}}\end{array}$ \\
\hline Sugar taken with fruit juice & $8.26 \pm 14.50$ & $3.18 \pm 5.32$ & $2.44 \pm 4.90$ & $5.00 \pm 10.24$ & 7.52 & $\begin{array}{l}0.004^{\mathrm{a}} \\
0.003^{\mathrm{b}}\end{array}$ \\
\hline Sugar taken with carbonated drinks & $3.98 \pm 6.95$ & $2.71 \pm 6.24$ & $1.95 \pm 2.96$ & $3.03 \pm 5.95$ & 2.03 & 0.13 \\
\hline Sugar taken with sweetened tea & $2.97 \pm 8.89$ & $1.76 \pm 4.34$ & $1.94 \pm 4.10$ & $2.28 \pm 6.48$ & 0.80 & 0.44 \\
\hline Sugar taken with sweetened soft drinks & $1.85 \pm 2.38$ & $0.90 \pm 1.88$ & $0.74 \pm 1.53$ & $1.23 \pm 2.07$ & 6.50 & $\begin{array}{l}0.008^{\mathrm{a}} \\
0.006^{\mathrm{b}}\end{array}$ \\
\hline Total sugar taken with sweetened beverages & $17.09 \pm 21.62$ & $8.56 \pm 14.53$ & $7.08 \pm 8.57$ & $11.34 \pm 15.32$ & 7.68 & $\begin{array}{l}0.004^{\mathrm{a}} \\
0.003^{\mathrm{b}}\end{array}$ \\
\hline Total & $24.30 \pm 2.58$ & $12.21 \pm 2.03$ & $9.24 \pm 1.47$ & $16.25 \pm 20.19$ & 12.56 & $\begin{array}{l}0.000^{\mathrm{a}} \\
0.000^{\mathrm{b}}\end{array}$ \\
\hline
\end{tabular}

Notes: $\mathrm{p}$-value $<0.05^{\mathrm{a}}=$ the level of significance between the $2^{\text {nd }}$ and $4^{\text {th }}$ grades; $\mathrm{p}$-value $<0.05^{\mathrm{b}}=$ the level of significance between the $2^{\text {nd }}$ and $3^{\text {rd }}$ grades; $\mathrm{SD}=$ Standard Deviation

\begin{tabular}{|c|c|c|c|c|}
\hline \multirow{2}{*}{ Variable } & \multirow{2}{*}{ Category } & \multicolumn{3}{|c|}{ Total Sugar Consumption (g) } \\
\hline & & n $(\%)$ & $\bar{x} \pm$ SD & p-value \\
\hline \multirow[t]{2}{*}{ Gender } & Male & $21(9.8)$ & $32.06 \pm 32.52$ & $0.024 *$ \\
\hline & Female & $193(90.2)$ & $14.53 \pm 17.65$ & \\
\hline \multirow[t]{2}{*}{ Obese individuals in the family } & Yes & $119(55.6)$ & $12.61 \pm 13.04$ & $0.006 *$ \\
\hline & No & $95(44.4)$ & $20.80 \pm 25.93$ & \\
\hline \multirow{2}{*}{ Regular breakfast } & Yes & $142(66.4)$ & $13.82 \pm 14.88$ & $0.039 *$ \\
\hline & No & $72(33.6)$ & $21.04 \pm 27.35$ & \\
\hline \multirow{2}{*}{ Eating before sleeping } & Yes & $127(59.3)$ & $19.28 \pm 23.33$ & $0.003 *$ \\
\hline & No & $87(40.7)$ & $11.82 \pm 13.36$ & \\
\hline \multirow{2}{*}{ Eating outside } & Yes & $131(61.2)$ & $16.74 \pm 21.94$ & 0.652 \\
\hline & No & $83(38.8)$ & $15.46 \pm 17.16$ & \\
\hline \multirow[t]{2}{*}{ Adding salt to meals } & Yes & $34(15.9)$ & $24.99 \pm 27.60$ & $0.041 *$ \\
\hline & No & $180(84.1)$ & $14.60 \pm 18.09$ & \\
\hline \multirow[t]{2}{*}{ Adequate and balanced nutrition according to students } & Yes & $87(40.7)$ & $12.69 \pm 14.54$ & $0.021 \%$ \\
\hline & No & $127(59.3)$ & $18.68 \pm 23.02$ & \\
\hline
\end{tabular}

Note: $\mathrm{SD}=$ Standard Deviation

20 -year-olds and over in the last 1 -month beverage is evaluated, blacktea was the most commonly consumed in both gender; it is drunk every day, $92.3 \%$ in urban and $94.5 \%$ in rural areas.

The effects of caffeine in tea on health should not be overlooked. Coffee, tea, cola drinks, cocoa, and chocolate contain caffeine. About $100-120 \mathrm{mg}$ of caffeine is in a cup of brine (200-250 mL), 40-50 mg infused in a cup of tea for 5 minutes, and $35-36 \mathrm{mg}$ is in $100 \mathrm{~mL}$ of cola. If taken more than 5 grams per day, congestion, coma, respiration, and heart failure can occur. ${ }^{23-25}$
According to data from TBSA, 22 the consumption frequency of herbal teas was generally low, with a total unconsumed rate of $71.2 \%$. The university students included in this study had a higher consumption frequency of herbal teas than the TBSA data. It is thought that university students are preferred because of the easy consumption of packaged herbal teas, and this situation contributes to an increase in the consumption of herbal tea.

Additionally, according to TBSA data, ${ }^{22}$ while $21.3 \%$ of people drink coffee or Nescafe every day. In this study, $20.6 \%$ of students declared that Nescafe was drunk at 
least once a day; similar results were obtained in both studies. In the same study, the rate of fruit juice consumption one to two times a week was $22.0 \%$, and the rate of consumption three to four times a week was $11.2 \%$. In this study, both rates were found to be $26.6 \%$ and $16.4 \%$, respectively. According to TBSA data, ${ }^{22}$ the rate of people consuming carbonated drinks daily was $11.7 \%$. At the same time, all of the students who participated in the study reported that they did not consume carbonated drinks every day. This outcome is incredibly rewarding because students in the Department of Nutrition and Dietetics have turned vocational education into a lifestyle. In the same study, the rate of people who did not consume alcoholic beverages was $84.9 \%$, compared to $89.7 \%$ in this study. Due to the drunkenness of alcohol in the Islamic world, it is thought that alcohol consumption is not considered legitimate.

Water is the essential component of nutrition. Every body function is supplied with fluid, and losing $10 \%$ of water causes serious problems in the body. Water and other beverages are important for the preservation of body fluid balance. An average of 2-2.5 liters (8-10 cups) of water per day is recommended to dispose of toxic substances through food consumption in the body and for the body's heat balance. 26,27 The average amount of water consumed by university students is $1228.04 \pm$ $533.5 \mathrm{~mL} /$ day $(6.15 \pm 3.41$ cups $)$ in this study, lower than recommended.

This study determined that university students' consumption of carbonated drinks, fruit juice, and sweetened soft drinks (mL/day) by university students decreased as the grade level increased (Table 2). In this result, vocational consciousness, abilities transforming knowledge to behavior and active course contents in students of the Department of Nutrition and Dietetics are considered to play an important role. The total amount of sugar added to drinks and the total amount of sugar taken in sweetened beverages were $4.69 \pm 6.35 \mathrm{~g} /$ day and $11.34 \pm$ $15.32 \mathrm{~g} /$ day, respectively, for students of the Department of Nutrition and Dietetics (Table 3). The total sugar added and sugar of sweetened beverages is approximately $44 \mathrm{kcal}$, equivalent to around $2.75 \%$ of the $2,000 \mathrm{kcal}$ diet. The energy given by the amount of sugar added to beverages or taken by sweetened beverages constitutes between $13 \%$ and $16 \%$ of the daily energy intake of adults and adolescents in the United States (US). 28

In a study of 253 university students, West, et al., 29 found that male and female students had $620 \pm 671$ $\mathrm{kcal} /$ day $(\sim 155-168 \mathrm{~g})$ and $505 \pm 670 \mathrm{kcal} /$ day $(\sim 126-$ $168 \mathrm{~g})$, respectively, $(\sim 135 \mathrm{~g})$ of energy when both groups were included, but this difference was not statistically significant. Murad, ${ }^{30}$ found that students studying at a university in the US, between 18 and 24 years of age, with 203 university students, had lower consumption of sugar added to beverages or taken by sweetened beverages as grade increases. According to Huffman and West, ${ }^{31} 201$ college students in the college preparatory period had a significantly higher rate of sugar consumption ( $\mathrm{p}$-value $<0.01$ ) than those who continue to study at university (p-value $<0.01$ ). Additionally, the average daily amounts of consumed sweetened beverages were 12.6 \pm 4.8 and $7.6 \pm 5.0$, respectively. The findings of this study were similar to those of Murad, 30 and Huffman and West, ${ }^{31}$; the students' daily sugar consumption was found to be lower than the study conducted by West, et $a l .{ }^{29}$ The main difference is thought to be that the students of the Department of Nutrition and Dietetics have turned the course content and nutritional education gained in this direction into a lifestyle.

In this study, students who have daily breakfasts compared to those who do not have, and students who think they are well fed and balanced compared those who do not had significantly lower ( $\mathrm{p}$-value $<0.05$ ) total sugar consumption (Table 4). Welsh, et al.,32, Collison, et al., ${ }^{33}$ and Gao, et al., ${ }^{34}$ found that the amount of sugar from sweetened beverages was significantly higher in men than in women ( $\mathrm{p}$-value $<0.005)$; Huffman and West, ${ }^{31}$ found no relationship between consumption of sweetened beverages and gender.

The Institute of Medicine, ${ }^{35}$ recommends that energy received by added or free sugar consumption should be less than $25 \%$ of daily energy. Further, the World Health Organization (WHO), 36 also recommends less than 10\% of the energy consumed. The American Heart Association, ${ }^{37}$ reports that energy taken from free sugars should be less than $150 \mathrm{kcal}(37.5 \mathrm{~g})$ and $100 \mathrm{kcal}(25 \mathrm{~g})$ for men and women, respectively. The United States Department of Agriculture, 38 recommends that energy obtained with solid fats and sugar should account for 5 $15 \%$ of daily energy. The $\mathrm{WHO},{ }^{39}$ on the other hand, points out that sugar energy is less than $5 \%$ of the daily energy requirement. Although international sugar consumption recommendations vary from country to country, it is suggested for our country that a maximum of 9$10 \%$ of energy ( $40 \mathrm{~g} /$ day for men, $30 \mathrm{~g} /$ day for women) should be consumed from sugar. ${ }^{39,40}$ Even though a maximum of $15 \%$ of the $2,000 \mathrm{kcal}$ diet (average $75 \mathrm{~g}$ ) was considered to be met by sugar, the results of this study indicate that university students have low sugar consumption. In this study, the amount of sugar taken from foods such as sweets and chocolate (one serving containing about $40-50 \mathrm{~g}$ of sugar) was not calculated. The only amount of sugar added to beverages or taken from sweetened beverages was determined.

In adolescence or adulthood, skipping breakfast is a serious problem, and this rate is close to $30 \%$ for young people in the US and European countries. Studies in the literature indicate that individuals who have a habit of 
having regular breakfast typically eat sufficiently and balanced. ${ }^{41-43}$ Although some studies, ${ }^{44,45}$ show that individuals who have regular breakfast have lower daily sugar consumption than those who do not, studies claiming the opposite of this situation, $46-48$ are available.

\section{Conclusion}

As the grades of Nutrition and Dietetics students increase, their sugary beverage consumption decreases. The eating habits of students usually shift positively. It should be evaluated to reduce the consumption of sugar and sugary foods and beverages in young people and develop recommendations for this, particularly regarding the prevention of chronic diseases in adults. In order to better understand these factors, it is important to plan and practice dietary habits, particularly in children and young adults, with regard to the consumption of soft drinks. Nutritional education, which is widely and efficiently provided, is essential to public health.

\section{Abbreviations}

SPSS: Statistical Package for the Social Sciences; TBSA: Türkiye Beslenme ve Sağlık Araştırması/Turkey Nutrition and Health Research US: United States; WHO: World Health Organization.

\section{Ethics Approval and Consent to Participate}

The study was approved by the Ethics Committee of Ankara University (Approval ID: 06-258-16).

\section{Competing Interest}

The author declares that there are no significant competing financial, professional, or personal interests that might have affected the performance or presentation of the work described in this manuscript.

\section{Availability of Data and Materials}

The data are not publicly available as it contains information that could compromise the privacy of research participants.

\section{Authors' Contribution}

ÇSM, NYA, and HÖY were involved in the design and conceptualization of the study, ÇSM and HÖY in data collection, ÇSM, NYA, and HÖY in data analysis, discussing the final results and contributing to the final manuscript.

\section{Acknowledgment}

ÇSM, NYA, and HÖY would like to thank the students of Ankara University, Faculty of Health Sciences, Department of Nutrition and Dietetics, who have agreed to participate in the data collection phase of the research and work devotedly.

\section{References}

1. Aller EE, Abete I, Astrup A, Martinez J, Baak MAV. Starches, sugars and obesity. Nutrients. 2011; 3 (3): 341-69.

2. Malik VS, Popkin BM, Bray GA, Despres JP, Hu FB. Sugar-sweetened beverages, obesity, type 2 diabetes mellitus, and cardiovascular disease risk. Circulation. 2010; 121 (11): 1356-64.

3. Park S, Onufrak S, Sherry B, Blanck HM. The relationship between health-related knowledge and sugar-sweetened beverage intake among US adults. Journal of the Academy of Nutrition and Dietetics. 2014; 114 (7): 1059-66.

4. Pulgarón ER. Childhood obesity: a review of increased risk for physical and psychological comorbidities. Clinical Therapeutics. 2013; 35 (1): A18-32.

5. Stanhope KL. Sugar consumption, metabolic disease and obesity: the state of the controversy. Critical Reviews in Clinical Laboratory Sciences. 2016; 53 (1): 52-67.

6. Armfield JM, Spencer AJ, Roberts-Thomson KF, Plastow K. Water fluoridation and the association of sugar-sweetened beverage consumption and dental caries in Australian children. American Journal of Public Health. 2013; 103 (3): 494-500.

7. Grimes CA, Riddell LJ, Campbell KJ, Nowson CA. Dietary salt intake, sugar-sweetened beverage consumption, and obesity risk. Pediatrics. 2013; 131 (1): 14-21.

8. Ranjit N, Evans MH, Byrd-Williams C, Evans AE, Hoelscher DM. Dietary and activity correlates of sugar-sweetened beverage consumption among adolescents. Pediatrics. 2010; 126 (4): e754-61.

9. Armfield JM, Spencer AJ, Roberts-Thomson KF, Plastow K. Water fluoridation and the association of sugar-sweetened beverage consumption and dental caries in Australian children. American Journal of Public Health. 2016; 103 (3): 494-500.

10. Yorulmaz H, Paçal F. 16-18 Yaş grubundaki gençlerin beslenme alışkanlıklarının ve obezite durumlarının incelenmesi. Türkiye Klinikleri Journal of Medical Sciences. 2012; 32 (2): 364-70.

11. Faydaoğlu E, Energin E, Sürücüoğlu MS. Ankara Üniversitesi Sağlık Bilimleri Fakültesinde okuyan öğrencilerin kahvaltı yapma alışkanlıklarının saptanması. Gümüşhane Üniversitesi Sağlık Bilimleri Dergisi. 2013; 2 (3): 299-311.

12. Büyük ET, Topçu S. İki farklı ilkokulda okuyan birinci sınıf öğrencilerinin beslenme ve fiziksel aktiviteleri arasındaki ilişkinin belirlenmesi. Düzce Üniversitesi Sağlık Bilimleri Enstitüsü Dergisi. 2015; 5 (1): 10-15.

13. Onurlubaş E, Doğan HG, Demirkıran S. Üniversite öğrencilerinin beslenme alışkanlıkları. Gaziosmanpaşa Üniversitesi Ziraat Fakültesi Dergisi. 2015; 32 (3): 61-9.

14. T.C. Sağlık Bakanlığı Temel Sağlık Hizmetleri Genel Müdürlüğü. Türkiye'de Okul Çağı Çocuklarında (6-10 Yaş Grubu) Büyümenin İzlenmesi (TOÇBi) Projesi Araştırma Raporu. 1. Baskı, Ankara: Kuban Matbaacılık Yayıncılık; 2011.

15. Akar F. Şeker ve hazır gıdalara eklenen fruktozun toplum sağlığı üzerine etkileri. Türk Farmakoloji Derneği Bülteni, Nisan - Haziran 2011, Say1: 108; 2011.

16. Fatihah F, Ng BK, Hazwanie H, Norimah AK, Shanita SN, Ruzita AT, et al. Development and validation of a food frequency questionnaire for dietary intake assessment among multi-ethnic primary school-aged children. Singapore Medical Journal. 2015; 56 (12): 687-94.

17. Rakıcıŏlu N, Tek Acar N, Ayaz A, Pekcan G. Yemek ve Besin Fotoğraf Kataloğu Ölçü ve Miktarlar Ata Ofset Matbaacıllk. Ankara; 2012. p. 131. 
18. The Coca-Cola Company. Product; 2020.

19. The Coca-Cola Company. Cappy; 2020.

20. Pepsico Beverages and Unilever. Lipton; 2013.

21. The Coca-Cola Company. Fanta; 2020.

22. Türkiye Beslenme ve Sağlık Araştırması. T.C. Sağlık Bakanlığı Sağlık Araştırmaları Genel Müdürlüğü, Hacettepe Üniversitesi Sağlık Bilimleri Fakültesi Beslenme ve Diyetetik Bölümü, Ankara Numune Eğitim ve Araştırma Hastanesi. Türkiye Beslenme ve Sağlık Araştırması 2010: Beslenme Durumu ve Alışkanlıklarının Değerlendirilmesi Sonuç Raporu. 2010; Sağlık Bakanlığı Yayın No: 931. Ankara; 2014.

23. Cano-Marquina A, Tarin JJ, Cano A. The impact of coffee on health. Maturitas. 2013; 75 (1): 7-21.

24. Rostagno MA, Manchon N, D'arrigo M, Guillamon E, Villares A, Garcia-Lafuente A. Fast and simultaneous determination of phenolic compounds and caffeine in teas, mate, instant coffee, soft drink and energetic drink by high-performance liquid chromatography using a fused-core column. Analytica Chimica Acta. 2011; 685 (2): 204-11.

25. Wikoff D, Welsh BT, Henderson R, Brorby GP, Britt J, Myers E, et al. Systematic review of the potential adverse effects of caffeine consumption in healthy adults, pregnant women, adolescents, and children. Food and Chemical Toxicology. 2017; 109: 585-648.

26. Popkin BM, D'Anci KE, Rosenberg IH. Water, hydration, and health. Nutrition Reviews. 2010; 68 (8): 439-58.

27. Jequier $\mathrm{E}$, Constant $\mathrm{F}$. Water as an essential nutrient: the physiological basis of hydration. European Journal of Clinical Nutrition. 2010; 64 (2): 115-23.

28. Ervin RB, Ogden CL. Consumption of added sugars among US adults, 2005-2010. NCHS Data Brief. 2013; 122: 1-8.

29. West DS, Bursac Z, Quimby D, Prewitt TE, Spatz T, Nash C, Eddings K. Self-reported sugar-sweetened beverage intake among college students. Obesity. 2006; 14 (10): 1825-31.

30. Murad M. Added sugar consumption among college students [Theses \& Dissertations]. Master of Science in Nutrition University of The Incarnate Word; 2017.

31. Huffman L, West DS. Readiness to change sugar sweetened beverage intake among college students. Eating Behaviors. 2007; 8 (1): 10-14.

32. Welsh JA, Sharma AJ, Grellinger L, Vos MB. Consumption of added sugars is decreasing in the United States. The American Journal of Clinical Nutrition. 2011; 94 (3): 726-34.

33. Collison KS, Zaidi MZ, Subhani SN, Al-Rubeaan K, Shoukri M, AlMohanna FA. Sugar-sweetened carbonated beverage consumption correlates with BMI, waist circumference, and poor dietary choices in school children. BMC Public Health. 2010; 10 (1): 234.

34. Gao X, Qi L, Qiao N, Choi HK, Curhan G, Tucker KL, et al. Intake of added sugar and sugar-sweetened drink and serum uric acid concentration in US men and women. Hypertension. 2007; 50 (2): 306-12.

35. Trumbo P, Schlicker S, Yates AA, Poos M, Food and Nutrition Board of the Institute of Medicine, The National Academies. Food and nutrition board of the Institute of Medicine, the National Academies.
Dietary reference intakes for energy, carbohydrate, fiber, fat, fatty acids, cholesterol, protein and amino acids. Journal of the American Dietetic Association. 2002; 102 (11): 1621-30.

36. World Health Organization. Nishida C, Uauy R, Kumanyika S, Shetty $\mathrm{P}$. The joint WHO/FAO expert consultation on diet, nutrition and the prevention of chronic diseases: process, product and policy implications. Public Health Nutrition. 2003; 7: 245-50.

37. Johnson RK, Appel LJ, Brands M, Howard BV, Lefevre M, Lustig RH, et al. Dietary sugars intake and cardiovascular health: a scientific statement from the American Heart Association. Circulation. 2009; 120 (11): 1011-20.

38. The United States Department of Agriculture. United States Department of Health and Human Services: dietary guidelines for Americans. Washington DC: U.S. Government Printing Office; 2010.

39. World Health Organization. Guideline: sugars intake for adults and children. Geneva, Switzerland: World Health Organization; 2015. p. 1-49.

40. Hess J, Latulippe ME, Ayoob K, Slavin J. The confusing world of dietary sugars: definitions, intakes, food sources and international dietary recommendations. Food Funct. 2012; 3: 477-86.

41. Briggs M, Fleischhacker S, Mueller CG. Position of the American dietetic association, school nutrition association, and society for nutrition education: comprehensive school nutrition services. Journal of Nutrition Education and Behavior. 2010; 42 (6): 360-71.

42. Pengpid S, Peltzer K. Skipping breakfast and its association with health risk behaviour and mental health among University Students in 28 countries. Diabetes, Metabolic Syndrome and Obesity: Targets and Therapy. 2020; 13: 2889-97.

43. Abd El Hakeem B, Abu-Melha S, Gad N, Alsheri M. Association between dietary habits and body mass index to female Students College Sciences and Arts Campus 1 at Khamis Mushayt King Khalid University. Food and Nutrition Sciences. 2015; 6 (14): 1316-23.

44. Afeiche MC, Taillie LS, Hopkins S, Eldridge AL, Popkin BM. Breakfast dietary patterns among Mexican children are related to totalday diet quality. The Journal of Nutrition. 2017; 147 (3): 404-12.

45. Lazarou C, Matalas AL. Breakfast intake is associated with nutritional status, Mediterranean diet adherence, serum iron and fasting glucose: the CY Families study. Public Health Nutrition. 2015; 18 (7): 130816.

46. Hassan BK, Cunha DB, Veiga GV, Pereira RA, Sichieri R. Changes in breakfast frequency and composition during adolescence: the adolescent nutritional assessment longitudinal study, a cohort from Brazil. PloS One. 2018; 13 (7): e0200587.

47. Brown AW, Bohan Brown MM, Allison DB. Belief beyond the evidence: using the proposed effect of breakfast on obesity to show 2 practices that distort scientific evidence. The American Journal of Clinical Nutrition. 2013; 98 (5): 1298-308.

48. Dhurandhar EJ. True, true, unrelated? A review of recent evidence for a causal influence of breakfast on obesity. Current opinion in Endocrinology, Diabetes and Obesity. 2016; 23 (5): 384-8. 